\title{
Developments in pharmacy-based sexual health services
}

\author{
Beth Taylor
}

\section{Background}

Pharmacies have always played an important role in sexual health service provision for both women and men, and in many ways they complement those available from other primary care and specialist services. These services may now embrace emergency hormonal contraception (EHC), chlamydia screening and treatment, and in 2008 oral contraception pilots are planned. This article describes the current context for pharmacy-based sexual health services and how these can be supported by specialist clinicians, and also highlights why pharmacists should be embraced within emerging local sexual health networks.

\section{What services are currently provided?}

Sexual and reproductive health (SRH) services available from pharmacies can be grouped according to how they are commissioned by the National Health Service (NHS) or are available to the public. In 2006, a new community pharmacy contractual framework was introduced which parallels that for general practitioners (GPs). This contract has three levels - essential, advanced and enhanced services - and each is considered in turn below.

\section{Essential services}

These must be provided by all pharmacies providing NHS services.

- Support for self-care, including provision of advice on products for over-the-counter (OTC) sale (including EHC, condoms, barrier preparations, fertility products, treatments for thrush, pregnancy tests).

- Signposting and referral of people to other services (e.g. GPs, genitourinary medicine or reproductive health clinics).

- Sexual health promotion as part of locally organised public health campaigns.

- Dispensing of NHS prescriptions relating to sexual health.

\section{Advanced services}

These may be provided only if the pharmacist has been accredited in accordance with national requirements and the pharmacy has a private consultation area.

- Medication use review.

This is currently the only advanced service and normally relates to more complex long-term medication.

\section{Enhanced services}

These are locally commissioned as needed by primary care trusts (PCTs) but some national template specifications have been developed.

- NHS provision of EHC through a patient group direction (PGD). Age restrictions regarding eligibility may be locally determined by PCTs.

- NHS provision of screening and treatment for sexually transmitted infections (STIs) including partner notification as required. Often initially chlamydia but can extend to other STIs.

J Fam Plann Reprod Health Care 2008; 34(3): 143-145

Community Health London, East of England and South East Coast Specialist Pharmacy Services

Beth Taylor, FRPharms, OBE, Joint Director

Correspondence to: Ms Beth Taylor.

E-mail: beth.taylor@live.co.uk
- Termination of pregnancy referral.

- NHS provision of treatments for minor ailments.

- NHS provision of long-term oral contraception via a PGD.

- Rapid HIV testing.

- Provision of SRH services via supplementary and independent prescribing.

PCTs may commission enhanced services to:

- Extend free NHS access to an OTC product (e.g. EHC).

- Extend access for those who do not pay prescription charges (e.g. minor ailments such as thrush).

- Extend choice by widening the local range of providers (e.g. chlamydia screening and treatment, long-term oral contraception).

PCTs will specify the requirements for both pharmacies (e.g. location, premises, opening times) and for individual pharmacists (evidence of relevant continuing professional development, training or accreditation). While all enhanced services are locally commissioned, the level of pharmacist expertise they require is variable. For those that offer free access to products which are already available for sale to the public significant additional requirements may not be needed, but provision of services that extend the pharmacists' current role in SRH will be dependent on individual pharmacists successfully demonstrating their competence as required by their PCT.

Pharmacists may also practise at an advanced or specialist level within the field of SRH. Practitioners to emerge so far often work within specialist HIV services, and recently consultant pharmacists have also been appointed. From 2007, pharmacists who combine their generalist role with a specific specialty (like GPs) can be locally accredited by PCTs as pharmacists with special interests (PhwSIs), and a national framework ${ }^{1}$ includes an exemplar in the field of SRH. This service model could allow a few pharmacists with substantial additional expertise in SRH to provide a more comprehensive local service, and also to participate in specialist networks and mentors and support their pharmacy colleagues.

\section{What are the public's views?}

Evaluation of pharmacy provision of SRH services to date $^{2,3}$ has highlighted common themes: public enthusiasm where this improves access and convenience, and acceptance of pharmacies as locations for service provision provided that they meet standards for confidentiality and privacy. Pharmacies have responded to this and over $75 \%$ now have a private consultation area or room. Pharmacists are required to keep confidential records of NHS care and apply Fraser guidelines for consultations with under-16-year-olds in the same way as other health professionals.

As more medicines and medical devices are available in pharmacies for purchase by the public new issues may arise. The recent Medicines and Healthcare products Regulatory Agency (MHRA) consultation on the reclassification of azithromycin ${ }^{4}$ raised some new issues including those outlined below.

- What additional training might pharmacists require to provide services linked to laboratories, and how might this be provided?

- What links should be developed between a non-NHS service and local specialist services?

- What form of partner notification and follow-up can be offered? 
Table 1 Key issues and challenges in the future development of community pharmacy services

\begin{tabular}{|c|c|c|}
\hline Issue & Pharmacy perspective & Pharmacy challenges \\
\hline $\begin{array}{l}\text { Increasing access, convenience } \\
\text { and choice }\end{array}$ & $\begin{array}{l}\text { Open access to pharmacies. Majority of opening } \\
\text { hours include Saturdays and some also include } \\
\text { evenings and Sundays. }\end{array}$ & $\begin{array}{l}\text { Sustainability re PGD services - need more locums } \\
\text { and second pharmacists who are also accredited. }\end{array}$ \\
\hline $\begin{array}{l}\text { Recognition of pharmacies as } \\
\text { sexual health providers }\end{array}$ & $\begin{array}{l}\text { Community pharmacies have always played a } \\
\text { major role in self-care, and are visited by the } \\
\text { public more often than other services. }\end{array}$ & $\begin{array}{l}\text { Despite this, NHS providers often overlook } \\
\text { pharmacists and they may not be represented in } \\
\text { key sexual health meetings or opportunities at PCT } \\
\text { level. }\end{array}$ \\
\hline $\begin{array}{l}\text { Resources to commission } \\
\text { pharmacy-based care }\end{array}$ & $\begin{array}{l}\text { Some services may be included within the } \\
\text { existing NHS contract (e.g. sexual health } \\
\text { promotion campaign) if chosen by the PCT. }\end{array}$ & $\begin{array}{l}\text { Where workload shifts from other NHS providers to } \\
\text { pharmacies (e.g. EHC) how can resources be freed } \\
\text { up and allocated in line with patient preferences? }\end{array}$ \\
\hline $\begin{array}{l}\text { Competency of the pharmacy } \\
\text { workforce }\end{array}$ & $\begin{array}{l}\text { Formal learning through HEls or the Centre for } \\
\text { Pharmacy Postgraduate Education courses is } \\
\text { widely available. Performance in new advanced } \\
\text { level roles may need to be assessed through } \\
\text { supervised practice. }\end{array}$ & $\begin{array}{l}\text { Current lack of infrastructure for supervised } \\
\text { practice in primary care (e.g. clinical supervisors). } \\
\text { Use of local practitioners/teachers (e.g. } \\
\text { nurses/medical staff) might be considered? }\end{array}$ \\
\hline $\begin{array}{l}\text { Where can pharmacy add value } \\
\text { to existing services? }\end{array}$ & $\begin{array}{l}\text { Popularity with some hard to reach populations } \\
\text { (e.g. partners for STI treatment; those for whom } \\
\text { appointments are a barrier to access). }\end{array}$ & $\begin{array}{l}\text { Advertising new services - how will the public know } \\
\text { where they are available? Would national 'branding' } \\
\text { (e.g. a pharmacy sexual health service logo) help? } \\
\text { How to manage inappropriate use of EHC PGD } \\
\text { services? }\end{array}$ \\
\hline $\begin{array}{l}\text { Pharmacy provision of } \mathrm{COC} \\
\text { and POP contraception }\end{array}$ & $\begin{array}{l}\mathrm{DH} \text {-led pilots are planned later in } 2008 \text {, and also } \\
\text { wider interest. Who for - new and/or repeat users? }\end{array}$ & $\begin{array}{l}\text { Initial work has supported inclusion of new users. } \\
\text { Pharmacists may need to access some training } \\
\text { resources currently aimed at nurses/doctors. }\end{array}$ \\
\hline $\begin{array}{l}\text { Chlamydia screening and } \\
\text { treatment }\end{array}$ & $\begin{array}{l}\text { Pharmacies can be commissioned to provide } \\
\text { screening or treatment or both. }\end{array}$ & $\begin{array}{l}\text { Although it may seem simpler to start with } \\
\text { screening alone and this addresses targets, the } \\
\text { biggest potential gain could be through increasing } \\
\text { access to treatment. Pharmacies are especially } \\
\text { well placed to provide this. }\end{array}$ \\
\hline
\end{tabular}

COC, combined oral contraception; DH, Department of Health; EHC, emergency hormonal contraception; HEI, higher education institution; NHS, National Health Service; PCT, primary care trust; PGD, patient group direction; POP, progestogen-only pill; STI, sexually transmitted infection.

- Within a non-NHS service, can data on prevalence and follow-up for treatment be collated?

- Will concerns about appropriate use of antibiotics be addressed?

The outcome of the consultation is not yet known but there are likely to be more applications of this nature in the future, which could have significant public support. Unless pharmacists become integrated into local SRH networks and develop relationships with specialists there is a risk

\section{SH service model}

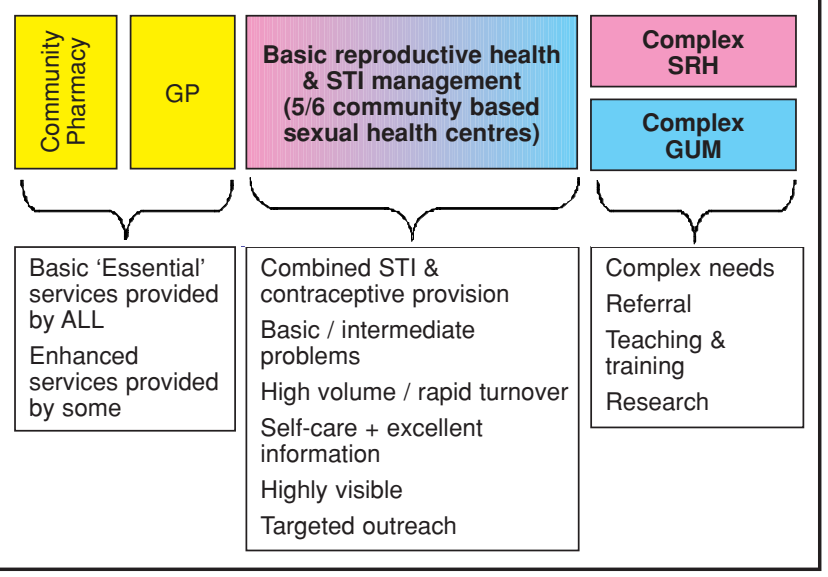

Figure 1 Outline of a future service model planned for the London boroughs of Lambeth and Southwark. GP, general practitioner; GUM, genitourinary medicine; $\mathrm{SRH}$, sexual and reproductive health; STI, sexually transmitted infection that any new services could develop in isolation or without access to key local information. This would be to the detriment of both the providers and the public, and supports the need for this issue to be addressed as soon as possible.

\section{How could services be developed in the future?}

Many commissioners and sexual health leads are keen to make more use of pharmacies and are considering pharmacy's potential role in their locality. Key issues and challenges in this regard are summarised in Table 1.

A final challenge that we all face is that relating to exemption from prescription charges. As more STI services rightly move into community settings, the current position whereby STI exemptions cannot be claimed for FP10 prescriptions is very frustrating for everyone, not least the pharmacist who is expected to collect the charge. A solution to this problem is urgently needed.

\section{Conclusion}

Now is the time for SRH service commissioners and providers to embrace the potential contribution of pharmacy, and to develop a vision of how this might be developed. In the London boroughs of Lambeth and Southwark, a systemwide modernisation programme has incorporated pharmacy-based services at several levels within a future service model (Figure 1) and full details of this are available on the Lambeth and Southwark Sexual Health website.5 Could this be a signpost to the future elsewhere?

\section{Statements on funding and competing interests}

Funding None identified.

Competing interests The author is a member of the National Chlamydia Screening Programme Advisory Group. 
References

1 Department of Health. Implementing Care Close to Home: Providing Convenient Quality Care for Patients. A National Framework for Pharmacists with Special Interests. 2006. http://www.primarycarecontracting.nhs.uk/uploads/Pharmacy/ PhwSI/launch_sept_06/phwsi_framework.pdf [Accessed 3 March 2008].

2 Bissell $\mathrm{P}$, Anderson C. Supplying emergency contraception via community pharmacies in the UK: reflections on the experiences of users and providers. Soc Sci Med 2003; 57: 2367-2378.

3 Department of Health. The National Chlamydia Screening Programme (NCSP). See Pharmacy Chlamydia Screening
Pathfinder Evaluation (PCSPf). Final: Wave Three under Related Links. 2007. http://www.dh.gov.uk/en/Publichealth/ Healthimprovement/Sexualhealth/Sexualhealthgeneralinform ation/DH 4084098 [Accessed 3 March 2008].

4 Medicines and Healthcare products Regulatory Agency (MHRA). Public Consultation ARM 43: Request to reclassify azithromycin $500 \mathrm{mg}$ from POM (prescription-only medicine) to P (Pharmacy). 2007. http://www.mhra.gov.uk/Publications/ Consultations/Medicinesconsultations/ARMs/CON2031517 [Accessed 3 March 2008].

5 Lambeth and Southwark Sexual Health Website (Modernisation Initiative). http://www.mysexualhealth.org.uk/ [Accessed 3 March 2008].

\section{FACULTY OF SEXUAL \& REPRODUCTIVE HEALTHCARE MEMBERSHIP EXAMINATION}

The Membership Examination (MFSRH) consists of:

\section{Part 1 Multiple Choice Question paper (MCQ))}

This 11/2-hour paper consists of 60 clinical science and applied science questions.

The examination will be held in London on Friday 17 October 2008. Applications must be received by 1 July 2008. The application form and information on the Part 1 can be obtained from the Faculty of Sexual and Reproductive Healthcare (FSRH) website (www.fsrh.org).

\section{$\square$ Dissertation or Case Reports}

Submission of one Dissertation (10 000 words) or two Case Reports (3000 words each). Information and forms appear on the Faculty website (www.fsrh.org). The closing date for submissions is 1 September 2008. After this date, candidates will no longer have the option to submit a Dissertation or Case Reports, or an exemption thesis. Candidates looking to submit after 1 September 2008 will find information on their replacement, Evidence Based Commentary, and Membership Examination Regulations (September 2008), by visiting the FSRH website (www.fsrh.org).

\section{$\square$ Part 2 Examination (CRQ, SAQ, OSCE)}

This all-day examination consists of:

- Critical Reading Question examination paper (CRQ)

- Short Answer Question examination paper (SAQ)

- Objective Structured Clinical Examination (OSCE)

Applications for the MFSRH Part 2 to be held in June 2009 must be received by $\mathbf{3}$ January 2009. Information on the Part 2 Examination, the Examination Regulations and the application form appear on the FSRH website (www.fsrh.org).

The qualification is subject to re-certification every 5 years.

For the current MFSRH Examination Regulations (December 2007), information on all components of the MFSRH examination and application forms, please visit the FSRH website: www.fsrh.org (see Training \& Exams and Membership Exam) or e-mail Denise Pickford at denise@fsrh.org. Examinations, Faculty of Sexual and Reproductive Healthcare of the Royal College of Obstetricians and Gynaecologists, 27 Sussex Place, Regent's Park, London NW1 4RG, UK. Tel: +44 (0) 207724 5629. Fax: +44 (0) 2077235333. 